\title{
Male-Female Differences in EFL Learning and Achievement in Morocco: Evidence from Beni Mellal
}

\author{
Driss Benattabou \\ English Department, Moulay Ismail University, Meknes, Morocco \\ d.benattabou@gmail.com \\ https://orcid.org/0000-0003-4240-1390
}

\begin{abstract}
Mounir Kanoubi
Institut Universitaire de Technologie, attached to the Rectorate of Rouen, France

Mounir.ka@gmail.com
\end{abstract}

\section{Abdelouahed Bouih}

English Department, Moulay Ismail University, Meknes, Morocco abdelouahed.bouih@gmail.com

https://orcid.org/0000-0002-2197-9479

\section{Bendaoud Nadif}

English Department, Moulay Ismail University, Meknes, Morocco bendaoudnadif@gmail.com https://orcid.org/0000-0001-6278-1808

$\&$

Mohamed Benhima

Sidi Mohamed Ben Abdellah University, Fez-Sais, Morocco

benhima01@gmail.com

https://orcid.org/0000-0002-4714-1471

DOI: http://doi.org/ 10.36892/ijlls.v2i3.671

Received: Abstract

The aim of this paper is to unravel some of the controversies which

15/07/2021 have often shaped the findings drawn from prior studies germane to the

Accepted: area of male-female differences in relation to language learning. Educationalists in Morocco have hardly looked at the sex variable as a potential parameter which may explain some of the differential success

19/09/2021

Keywords:

Sex differences, EFL

learning, Male-

female students,

Achievement levels of students in schools, and little if not daring to say none is known about it in the Moroccan context where there is still much to be done in terms of research and investigations. This study sets out to fill in this gap in research by analyzing male-female differences in language leaning. Using results of a test battery, regional exam GPA, and a standard EFL achievement test, quantitative data of a large group of senior high school students constituting a non-probability convenience sample $(N=152)$ drawn from the official records of Zerktouni high school, Beni Mellal directorate, have been explored to gather information about the issue in question. The results from the ChiSquare test and the independent samples t-test prove very convincingly that female learners unequivocally outperform their male peers at almost all basic language skills. The paper ends up with a conclusion and some pedagogical recommendations. 


\section{INTRODUCTION}

In line with the recent trends which have endorsed the learner-centred approach, a host of many research studies have shifted the focus of their emphasis from teacher-centred approaches to consider the importance of learners' variables as potential determinants of success or failure in language learning. Research on sex differences in relation to language learning has evolved out of this steady surge of interest in individual learners' variables and on humanitarian approaches to education.

Perhaps one of the fundamental conundrums in the theory of language learning is the differential achievement levels of male and female students. Although much research has been undertaken to explore the effects of individual learners' variables namely age (Schumann, 1980; Burstall, 1981; Flege, 1987; Ellis, 1995; Svanes,1987; Johnson \& Newport, 1989), personality traits (Brown, 1986; Dulay et al., 1982; Strevens, 1983), and attitudes and motivation (Lambert, 1969; Gardner \& Lambert, 1972; Gardner, 1985, 1988; Dornyei \& Ottó, 1998; Dornyei \& Csizér , 2005), the variable of sex remains one of the learners' factors which has seldom been isolated for scrutiny in research studies pertaining to language learning (Oxford, 1992; Bacon \& Finneman, 1992; Sunderland, 1994; Ehrman \& Oxford, 1995).

Prior research on male-female differences has been extensively examined in the field of psychology and neurophysiology (Maccoby \& Jacklin, 1974; Ekstrand, 1980). The relevance of sex differences in second and foreign language learning is still understudied and under researched. The paucity of cross-sex comparison is considered to be particularly "lamentable" (Alexander \& Eckland, 1974), and arguments have often been voiced to note that the issue has not received as much attention as it really deserves (Boyle, 1987; Oxford, 1992; Sunderland, 1994; Byrne, 1994; Bacon \& Finneman, 1992; Ehrman \& Oxford, 1995).

As a matter of fact, the issue of sex differences in language learning is partially explored and should therefore be put "firmly on the agenda" (Sunderland, 1994, p. 8). Oxford et al. (1988) seem to capture the essence of the problem arguing that:

[The] omission of sex as a variable in language learning strategy research is rather surprising, since sex is a classic and significant predictor in other educational, psychological and linguistic research.(p. 321)

According to Sadiqi (2003, p. 35), "studies in language and gender are barely known in Morocco and the Arab-Islamic world at large." It is not until the early twenties that a surge of interest in women studies has been brought into the surface through the creation of two research centers in Morocco, namely 'The Centre for Studies and Research on Women' in Fez, and 'The Center of Women's Studies' in Rabat. These two research centers:

Aimed to fill the gap in the domain of gender/women's studies, to contribute to the development of scholarly research and to change social perceptions, attitudes, and structures that obstruct gender equality. (Sadiqi, 2011, p. 27).

The burgeoning interest in this uncharted area indicates that the important role sex plays in language learning has been gradually recognized (Oxford et al., 1988; Bacon \& Finneman, 1992; Oxford, 1992; Sunderland, 1994, 2000; Wen \& Johnson, 1997; Jiménez, 2003; Główka, 2014; Benattabou, 2020, 2021). It would be undeniable to contend in this respect that there have been few attempts to explain the differential results of learning by calculating the correlation between the variable of sex and the learners' scholastic attainments. It is quiet disturbing, however, that the empirical research currently available investigating the problem is perhaps spotty and somewhat inconsistent (Ekstrand, 1980).

Because of these problems and other yet undiagnosed ones, Sunderland (1994) argues convincingly that research on gender differences in language learning is still in its embryonic stages, "patchy", and should therefore be given a top priority than in the research agenda.

In view of the gaps in the empirical research and the practical concerns for this area, the present study sets out to make further investigation of the relationship between sex and 
foreign language performance among a group of high school students in a cultural setting perhaps completely different from the settings where previous research was carried out, and, hopefully, attempts to scrutinize the complexity involved in unravelling a satisfactory interpretation of the results. Attempts will be made to uncover some of the controversies which have often shaped the findings drawn from prior studies germane to this arena.

With this picture in mind, the following section attempts to present in a more comparative fashion some of the general issues associated with gender differences with regard to language attainments. A synthesis of the bulk of research pertaining to this question would be pointed out in the hope of exploring the proliferating literature on this topic.

The first section of this paper presents a review of the literature surveying in a critical way the bulk of research related to the issue of the differential success of male and female students in relation to language learning abilities. This background information regarding prior research in the differential success of male-female students in language learning will surely help untangle and unpack a number of subtle myths surrounding this newly emerging area of research. The second section will present the methodological steps undertaken to carry out this study. Section three will be essentially concerned with a presentation of the results along with a discussion of the multiplicity of assumptions and hypotheses which have been stipulated so far to explain the disparity between the two sex groups. The paper ends up with a conclusion and some recommendations.

\section{1.Sex Differences and Language Learning: A Review of the Literature}

Educational research on the issue of male-female differences in second/foreign language learning is rife with remarkably opposing assumptions and quite incongruous findings. When considering prior surveys related to this topic, one would not probably miss a feature so striking to the eye, namely the existence of three notable but contrasting trends. The general picture emerging from this literature points to a pattern of clearly distinguished results, some arguing for females' superiority in language learning, some others stressing that better commands are in the favour of males, while others reporting negligible or no relationship at all.

\subsection{Evidence for girls' superiority in language learning}

There is more evidence in the literature indicating female learners' superiority at almost all academic areas of language learning. The general hypothesis underlying much of the literature to be addressed in this subsection is that female students are far more likely to excel in virtually all the verbal and linguistic abilities than the corresponding male group (Kinard \& Reinherdz, 1986; Licht \& Dweck, 1983; Mickelson, 1989; Eherman \& Oxford, 1989; Halpern, 1992). The term verbal ability has been used to refer to such language skills as grammar, vocabulary, reading, spelling, and oral comprehension (Halpern, 1992).

In a more extensive review of sex differences in relation to learning, Ekstrand (1980) cites evidence from Maccoby and Jacklin (1974) indicating that girls score significantly higher on tests measuring verbal abilities. In this survey, Ekstrand (1980) enumerates a list of large number of studies where it has been shown that thirty-six investigations have reported results favoring girls, while only thirteen of other studies have given results favoring boys.

Burstall (1981), in her longitudinal investigation of British learners, takes a stance completely similar to that outlined by Ekstrand (1980). The author's data have yielded consistent results indicating that girls have achieved higher and better grades on tests tapping their general knowledge of French. Burstall (1981) goes on to argue that girls' tendency to perform well in second language learning may presumably be the result of their being more positively oriented towards the learning of languages than boys. 
In a similar line, further evidence in accord with the results surveyed above comes from Riding and Banner's (1986) study of British male and female students learning French as a second language. Riding and Banner (1986) have reached essentially the same pattern of results; the mean score attained by girls has been reported to be appreciably superior to that of boys on tests exploring their performance of French. The statistical differences between the two sex groups are quiet discernible, for the general means are respectively, overall girls 63.83 per cent, boys only 36.17 per cent (Riding \& Banner, 1986).

The gap in achievement levels among male and female learners, Powell (1979) goes further to contend, is very large to be of more than a coincidence. Powell (1979) seems more inclined to regard this superiority as an indication of a special female capacity to succeed in language learning. Crucially important here is the author's general assumption that female adolescents have a distinct advantage over males, an advantage which he seems unfortunately unable to explain.

The general hypothetical tendency that girls are likely to outperform boys in nearly all the verbal tasks of the second/foreign language has gained much support from another stream of research concerned with the same issue (Stockard \& wood, 1984; Woodley, 1984 ; Mickelson, 1989; Licht et al., 1989; Halpern, 1992). Of particular interest in this regard is Stockard and Wood's (1984) investigation of underachievement among Oregon secondary school students; the results have demonstrated that failure to achieve better commands in learning is much more common among boys than among girls.

While reporting the same pattern of differences attributed to sex, Ehrman and Oxford (1989) have taken a different, but related, direction in research comparing the distinct strategies used by males and females to learn second/foreign languages. The findings of this research have revealed that more female learners reported using more learning strategies with significantly greater frequency than males. Additionally important, girls have displayed an increasingly stronger tendency to engage in language social interactions with others outside the classroom setting (Ehrman \& Oxford, 1989).

Sunderland's $(2000,2010)$ research seems to reflect almost the same patterns of results. Her studies examining the relation between language education achievement and gender have found that, in some contexts, females may have more inclination to study foreign and second languages and that they are far more likely to outperform males since they get influenced by gender ideologies and practices (Sunderland, 2000, 2010).

Following the same line of reasoning, Miller and Dale (1972) have gone a little bit further to suggest that the superiority of female learners does not manifest itself only in language abilities, or what is referred to as arts, but also in science studies as well (Miller \& Dale 1972). Such an argument, however, is inconsistent with studies which endorse the claim that mathematical ability is often perceived as a "male domain" (Ekstrand, 1980; Halpern, 1992). Halpern (1992), in particular, goes on to maintain that since mathematical skills are considered as " unfeminine" in nature, girls would be more likely to lag far behind in their performance in it than boys (Halpern, 1992). This view is shared by Ekstrand (1980) who contends that, unlike girls, boys have been found to excel in mechanical abilities. A study carried out by Lindberg et al. (2010) reported that males outdid females in mathematics achievement tests as age increased, with a significant increase in high school and a decrease in university and adult samples.

Back to our discussion of female's superiority in language learning, there is also some evidence that girl's efficiency in manipulating verbal abilities is manifested at a quite an early age in infancy (Oakley 1972; Kipnis, 1976; Powell 1979; Halpern, 1992). Girls have been reported to speak their first word sooner, construct words to form longer sentences earlier, and they are likely to develop faster than do boys in the expressive use of their native language (Kipnis, 1976; Ekstrand, 1980).

In agreement with this assumption, Oakley (1972) asserts that there is an essential tendency among female learners to be distinctly better in displaying greater grammatical 
competence, and to be much more accurate in initiating more verbal exchanges throughout the school years. Likewise, it is believed that girls are more intrinsic than boys in terms of classroom curiosity and are likely to predominate in aspects such as class discussion (Green \& Foster, 1986). This tendency is also documented by Coates (1986) and Woodley (1984) who come to a similar conclusion, namely that girls tend to graduate more than boys, and are less likely to fail on academic grounds.

One salient feature that has emerged from the above line of argumentation is that where sex differences are found in the first language, it has usually been proven to be the case that female learners tend to outperform their male counterparts (Kipnis, 1976). It is, however, very disturbing in the light of these conclusions how girls' superiority in the mother tongue may be translated into success in mastering second and/or foreign languages. This argument seems to substantiate Powell's (1979) hypothesis that girls' good attempt to "manipulate items of the mother tongue is deemed applicable to second language learning." (Powell, 1979, p. 22)

Similar findings have been reported in more published studies concerned with the same issue. Coates (1986), in specific, reports a more global view of language learning indicating female students' more proficient levels along almost all language skills . Coates (1987) reports in this connection that "at any age, girls will be found to be superior in terms of comprehension, size of vocabulary, reading ability, handling of complex expressions such as the modals, etc.:"(Coates, 1986, p. 123)

On a similar note, Boyle's (1987) study of 490 Chinese university students in Hong Kong suggests the same findings. There is a general tendency among female students to achieve overall higher mean scores in ten tests of general L2 English proficiency. Chambers (1992) sustains the same view echoing nearly the same pattern of results:

Over many years, women have demonstrated an advantage over men in tests of

fluency, speaking sentences complexity, analogy, listening comprehension, of

both written and spoken material, vocabulary and spelling. (p. 199).

In another research study, Murphy (2010) argues that the results elicited from data collected on the basis of male-female differences in second-level Irish schools between 2003 and 2007 suggest more important advantages favoring female students performing much more better in three foreign languages, namely French, German and Spanish. Similar patterns of results have been recently surveyed in other research studies (Fergusson \& Horwood, 1997; Camarata \& Woodcock, 2006; Główka, 2014). Chief among these is Główka’s (2014) most recent investigation studying the differential success of male and female subjects learning English in Polish state schools. The results of this study seem to corroborate the same observation that female language learners are found to be more successful in language learning than their male counterparts.

Another part in sex-related research has been undertaken to analyze male-female differences targeting very specific skills of language learning. With respect to listening comprehension, Farhady (1982) examined measures of language proficiency among male and female students. Relying on results drawn from a placement test among a group of 800 university students, he observes a noticeable superiority of female students regarding their listening comprehension. This may support at least in part Eisenstein's (1982) finding that females tend to surpass and outstrip males with respect to their exceptional ability to discriminate among different American English accents.

Similar findings have been echoed in Nyiko's (1990) investigation of male and female disparities in relation to the learning of German. The study points to female students' higher performance grades in the memorization tests of the German vocabulary.

Comparable evidence in support of female language learners' superiority in language learning emanates from the differential success of male/female performance in writing. 
Central to this view is Morris's (1998) examination of male/female students regarding their scores on ESL writing in Quebec. Higher proficient levels of the writing skill have been reported favoring female students. He attributes this mastery to female students' tendency to conform to the instructions and rules of writing, as well as to their better manipulation of learning strategies.

Peterson's (2000) study of the writing skills of the two sex groups seems to suggest similar results in support of female students' more proficient levels in writing. As opposed to male students' writings, female students' composition skills seem to display their academic propensity to write in a more detailed and descriptive way in sound conformity to the basic conventions of writing.

Research on more academic areas of studies seems to suggest the same conclusions. Bugel and Buunk's (1996) investigation of male and female students in the Netherlands is worth mentioning here. The researchers concluded that female students tend to perform much better in topics culturally considered as feminine.

In a very recent study in the Moroccan context, Hdii and Fagroud (2018) examined the differences between females and males regarding both their enrollment rate as well as their academic performance. The data includes students' exam scores at the National School of Agriculture in Meknes, Morocco. Of special concern to us here is the scholastic attainment of the two sex groups in English. The results yield significant gender achievement gaps pointing towards the superiority of female language learners compared with their male peers.

One further issue which $I$ we believe deserves to be mentioned here, and is particularly relevant to our discussion is Carroll's (1978), and Lewin and Massad's (both cited in Powell, 1979) wide generality of the claim that females' superiority is a worldwide feature. Although these two studies maintain essentially the same pattern as previous research, they seem inclined to argue that female students' tendency to achieve better commands in language learning is universal and is likely to manifest itself across-cultures.

However, following Hartley (1978), one is reasonably led to contend that it is surprising in an area as controversial as the one under consideration to assume wide generality in the statement, mainly because there may possibly be marked sex differences from one cultural setting to another (Boyle, 1987; Hartley, 1978).

Importantly enough, individual studies suggest that an asset is found in favor of females in elementary schools (Pomerantz et al., 2002), middle schools (Mickelson \& Greene, 2006), and high schools (Mc Cornack \& Mc Leod, 1988). In higher education, however, findings tend to vary. In fact, some researchers reported a female lead across different disciplines (Mc Cornack \& Mc Leod, 1988). In the same direction, research investigating academic achievement highlights the expectation that females should outperform males in all disciplines (Pomerantz et al., 2002).

\subsection{Evidence for boys' superiority in language learning}

Somewhat different results are found in some other researches advancing arguments which are completely incongruent with the above surveyed studies. The rationales stipulated in this connection rest on the assumption that male learners are more capable of achieving higher mean scores on some aspects of the second/foreign language verbal skills (Boyle, 1987). Males are also reported to issue much more influential contributions in achievement situations than girls (Batters, 1986; Collis \& Williams, 1987; Rychman \& Peckham, 1987).

In a review of research on academic underachievement, Hutt (1979) concludes that girls are persistently found to underachieve in school more often than males. Hutt's (1979) arguments seem to challenge the educational system in England which, according to her, "while greatly improving the performance of boys, did little for the performance of girls." (p. 25). One can easily notice, however, that her argument hangs on the unreasonable assumption that girls' failure is merely a direct result of their being in mixed, or what she refers to as "co-educational" schools with boys. In this context, boys are reported to do 
appreciably better while girls tend to be at a disadvantage (Hutt, 1979). In support of this claim, the author cites evidence from Dale's study (1974).

However, a closer scrutiny of such evidence would perhaps reveal that Hutt's (1979) beliefs are somewhat far-fetched to be true. This could be attributed to the fact that Hutt, $I$ we suppose, might have misunderstood Dale's (1974) fundamental findings. Contrary to Hutt's (1979) contention, Dale (1974), while comparing boys' and girls' attainments in single-sex and co-educational schools, comes to the conclusion that, juxtaposed with their make peers, girls perform better when it comes to learning of French (Dale, 1974).

With reference to girls' failure and underachievement, subsequent research seems to report actually the same pattern of results. Central to this view is Ryckman and Peckman's study (1987). Citing evidence from Dweck and Licht (1980), Ryckman and Peckman (1987) argue that female learners often rate themselves poorly, and are more likely to enter intellectual situations with lower expectations of success than do males.

This pattern of argumentation is roughly consistent with Collis and William's (1987) finding. Among a group of Canadian secondary school adolescents, it has been found that girls tend to be less self-confident regarding their achievement-related beliefs in writing. Boys, by contrast, have been reported to be considerably more positive in terms of selfratings as far as this skill is concerned (Collis \& Williams, 1987).

Boyle (1987) also provides an interestingly important study on the relationship between sex and second language learning. The subjects of this empirical study are all native speakers of Chinese for whom English is a second language. The tests are purported to measure the general language proficiency of Chinese boys and girls with more focus on their ability to comprehend spoken vocabulary. Boyle's (1987) results have shown that there is a tendency for girls to do better in general language ability. Males, however, have been reported to be much more superior and to have higher mean scores than females in tests of listening vocabulary.

To back up his own finding, Boyle (1987) contends that this unusual phenomenon of sex differences in listening ability is supported by arguments which maintain the view that during the early stages of first language acquisition, mothers are supposed to "respond more to male infants' vocalization than to females" (Scherman, 1978, cited in Boyle, 1981, p. 282).

Still, Boyle (1987) seems to be reluctant to accept this argument as an adequate explanation to account for boys' efficiency, opting instead for the assumption that males' wider experience to engage in various social interactions may possibly be applied in the context of second language learning (Boyle, 1987). This hypothesis seems to share the same criticisms articulated above in that one is surprisingly left to wonder that its rationales might hold true merely in first language acquisition, and may seem inadequate to explain the weight of evidence in favor of boys' superiority over girls in second language listening vocabulary. If we accept Boyle's (1987) assumption that boys' mastery of Chinese is applicable to their learning of English, there seems to be no reason whatsoever why girls are discarded from this advantage.

A related issue that is important to touch on with regard to boys' supposed efficiency in language learning appears in research concerned with sex-related differences in class participation. Collis and Williams (1987) have compared males and females on verbal ability; the results have shown that males predominate in class discussion, and are much more likely to outweigh girls in rate of participation. Gall and Gall (1976, cited in Dillon, 1982) endorse essentially the same view namely that males are more actively involved in the classroom, interacting more often and issuing more valuable and influential contributions than females.

Also consistent with these results is Batters' (1986) study which has demonstrated that there is a general tendency among males to engage more in foreign language discussions. 
Additionally, it has been reported that boys tend to hold more positive reactions to oral work than do girls. Surprisingly, however, Batters (1986) has carried this assumption further to suggest that boys are more likely to dominate the linguistic space regardless of the lesson.

Recent research in the literature, though very few, continues to emerge indicating better performance levels among males but not females. Although there is a tendency to suggest findings favoring male students, one is reasonably led to contend that this is the case merely with some aspects of the receptive skills.

Boyle's (1987) comparison of male-female students' performance on two tests of listening vocabulary indicates better attainment scores favoring males. Unlike females, male Chinese students of English have been observed to be superior in vocabulary and recognition listening tests.

In another study, Markham (1988) points out that English as a Second Language learners are far more likely to understand male speakers better than female speakers. Male speakers are considered to be more "expert" than females.

Bacon's (1992) investigation echoes the same findings pointing towards male students' proficiency regarding listening comprehension skills. Bacon (1992) further contends that this superiority among males is reflective of their confidence linked to performance on the listening comprehension test.

On a somewhat similar note, Scarcella and Zimmerman (1998) report similar research findings. Male students have been found to display more competence in vocabulary recognition, understanding and use. Almost the same results have been echoed in Lynn et al.'s (2005) more recent study of the same issue. Male students receive more attainment levels with respect to their vocabulary knowledge in the foreign language than their female peers.

Studies of sex differences in interactions among ESL learners seem to suggest that male students are far much better at debating and expressing opinions. Females, however, have been found to facilitate verbal exchanges in these cross-sex interactions (Gass \& Varonis, 1986).

Subsequent to this, Graham and Rees' (1995) study examining gender differences at a secondary school in England indicates that female students, being more affected by anxiety than males, tend to underachieve and face many problems in oral tasks.

\subsection{Sex differences and language learning: Arguments for a negligible link}

While there are patterned differences attributed to the parameter of sex in relation to language learning, there is a more disturbing feature surrounding the proliferating literature, namely that of a different trend which seems to stipulate other more conflicting arguments. The salient feature underlying most of the research here is that there are negligible differences, and there seems to be a claim for the superiority of neither sex.

As is previously mentioned, research on sex differences in relation to language learning is contradictory, patchy, inconclusive, and is still under explored. The third pattern of results linked with the literature on the differential success of male and female students seems to imply that the gender issue is either irrelevant or is not significant enough to make any difference.

In a research study conducted among a sample of Nigerian pupils learning English as a second language, Williams (1981) has attempted to assess the significance of some factors, particularly age and sex, in relation to attainments in the reading of English. His results have shown that the sex variable has not contributed to the prediction of learners' reading performance scores. Such finding has led Williams (1981) to assume that the parameter of sex is one of the least important factors which could reliably predict success or failure in second language learning.

Data from other research seem to yield roughly the same pattern of results. Connor (1983), for instance, endorses a similar conclusion arguing for an insignificant correlation 
between the learners' sex and their second language reading achievements; students' reading performances are reported to be not affected at all by their sex. The same view is shared by Thompson (1975) who reasons that by the age of ten or over, sex differences are no longer apparent in reading attainments.

A look at the issue from an overall framework will certainly indicate that Thompson's (1975) assumption calls for certain reservations. Some variables of crucial importance have been undermined in his study, particularly the interlocking and complex interaction between age and sex. Much of the research conducted in this area tends to stress the view that sex differences do not become sharpened and significant until a later stage of one's life (Kfir, 1988; Hartford, 1978; Pritchard, 1987). Highly suggestive perhaps here is Stockard's (1980) contention which has taken the same stance affirming that sex differences become notably more pronounced at adolescence period.

Particular grounds for discontent may be evident too in Hennessy and Merrifield's (1978) research assessing the effects of the learners' sex upon their level of academic performance. The authors have demonstrated that general measures of the verbal skills are not directly influenced by the learner's sex. Under this hypothesis, the authors have concluded that the parameter of sex has no determining role in predicting performance on verbal factors.

In agreement with the above line of reasoning, but at a variance with Collis and Williams (1987), Dillon (1982) reports a negligible difference between males and females' performance in the classroom setting. In an attempt to determine whether boys tend to speak more in the foreign language classroom than girls or vice-versa, Dillon (1982) has attempted to compare the kind of participation in which the two sex groups are involved. Contrary to common speculation made elsewhere (Batters, 1986; Collis \& Williams, 1987), Dillon (1982) comes to a very distinct conclusion that the observed differences in participation among males and females display "no imbalance, disproportion, or predominance." (p. 352).

Similarly, Ludwig's (1983) study comparing between male and female students at the university level indicates no significant differences in attainment between the two sex groups. Another study of adult male and female Japanese learners of English as a second language, conducted by Pica et al. (1991), found no sex differences at the level of interaction between the two sex groups.

Jiménez and Terrazas (2008) seem to argue that there is absence of any empirical evidence in corroboration of the view that there are sex differences in relation to language learning. The study indicates no significant differences between male and female students with regards to their performance in a receptive vocabulary test.

A further and most recent study adds more evidence to the null hypothesis. Soori and Zamani (2012), as a case in point, indicate that male and female writing skills display equal manipulation of most language-based features and there seems to be no differences between them.

In view of the controversy surrounding the field of gender differences in language learning, one is led to contend, as Ekstrand (1980) does, that the problem of investigations reporting no sex differences, as is the case with Albani and Sewell (1979); Williams (1981); and Connor (1983), among others surveyed above, may be accounted for by the fact that in these studies sex differences "have been computed only as a by-product of researches with other objectives" (Ekstrand, 1980, p. 211). Putting the matter succinctly, we would agree with Ekstrand (1980), that while these studies might have distinct advantages, they seem to have a definite limitation. Indeed, the effects of sex as a single variable might have become extremely obscure and blurred in such multivariate studies.

It is perhaps surprising that the abundance of works on gender in relation to learning and achievement in North American and to a lesser extent West European contexts, both 
related to scholastic and academic achievement on the one hand, and on EFL achievement on the other hand, stands in sharp contrast to what is available in the Arab world in general and in Morocco in particular. Therefore, it is only judicious to call for more researcher efforts to be invested in these particular social environments where the issue has not received its due attention.

Although there has been some recent research focusing on the same subject in Morocco stressing the superiority of females both with respect to their performance in EFL and academic achievement (e.g. Hdii \& Fagroud, 2018; Brigui, 2017; Ibourk, 2013; Zohri, 2011), the phenomenon of sex differences in relation to language learning is still in its preliminary stages. Similarly, there are some conflicting results emerging from the Moroccan educational system presenting counter-evidence to female language learners' constant superiority (Zaid, 2020). Based on all of this, one is reasonably led to argue that research in Morocco is still in its infancy which may surely justify the relevance of the present study.

We believe there are multiple reasons that justify the importance and the significance of the present study. First, this investigation is an attempt to contribute to the scant literature on sex differences in academic achievement in Morocco through presenting new evidence in support of the male-female differential success with special reference to a local Moroccan high school setting. Further, we make a valuable precedence detailing the aspects of language skills concerned with achievement which paves the way for larger and more comprehensive empirical investigations in gender differences studies.

This study sets out to answer the following four research questions using our localized convenience sample of senior high school EFL learners:

1. Does gender have an effect on EFL success in the Moroccan context, in Beni Mellal?

2. Do female learners surpass their male peers with regard to academic achievements in the Moroccan context, in Beni Mellal?

3. Are there any significant differences in the achievement levels of male and female students learning EFL?

4. Is this difference in the achievement levels of both male and female students significant across the three language skills under study?

From these questions stems four corresponding positive hypotheses stated as follows:

1. Gender has an effect on EFL success in the Moroccan context, in Beni Mellal;

2. Female learners surpass their male peers with regard to academic achievements;

3. There is a significant difference in the achievement levels of male and female students learning EFL in the Moroccan context, in Beni Mellal;

4. The difference in the achievement levels of both male and female students is significant across the three language skills under study.

\section{METHODOLOGY}

\subsection{Research design}

The present study is fundamentally analytical and observational in nature. Our crosssectional inquiry examines by means of group comparison the statistical significance of the score differences between male and female EFL learning senior high school students using a large group $(\mathrm{N}=152)$ comprised of multiple classes from one high school in Beni Mellal obtained using convenience sampling.

Using the chi-square test to explore the effect of gender on academic and EFL achievement as a preliminary step to further the gender-based group comparison using the independent samples t-test, we set out to examine firsthand authorized official school records to confirm or disconfirm our research hypotheses positing essentially a female-lead success and academic over-performance. 


\subsubsection{Data collection procedures}

\subsubsection{Population}

The general objective of this paper is to explore the differential success of male and female students learning EFL in the Moroccan context. For this purpose, we consulted the administration of Zerktouni high school, Beni Mellal directorate, which is located in the regional academy of Beni Mellal Khenifra, and has the capacity of accommodating 1300 students in different streams, namely physical sciences, biology sciences, human sciences and arts. We obtained the scores of students enrolled in the academic year 2020-2021. One hundred and fifty two $(\mathrm{N}=152)$ students, of whom 75 are males and 77 are females whose age ranges between 17 and 18 , were selected through convenience sampling. The grades, distributed along three language achievement subtests (Reading Comprehension Grades=152; Composition Test Grades =152, and Grammar and Language Test Grades=152), were collected and analyzed. These three tests have been selected because they are assessing students' language-based skills. The 152 grades we have sampled represent the total number of students who received a non-disqualifying score in the three achievement tests of the Spring Semester exams of 2020-2021. Additionally, the first Baccalaureate year 2019-2020 regional exam test results were collected along with the previous scores. These scores have been selected depending on the criteria of convenience sampling. First, the scores were elicited from different classes of students registered in the second year Baccalaureate in Zerktouni high school. Second, three exam grades were sampled mainly because, unlike other course grades, they represent such language-based skills as reading comprehension, composition and grammar. Third, all these students are registered at the Zerktouni high school, Beni Mellal, Morocco. This implies that these students are taught by the same teachers, being subject to the same syllabus, and undergo the same learning conditions.

\subsubsection{Research Materials and Procedures of Analysis}

In order to examine the relationship between the variable of sex and language learning, an achievement test of English was administered to these students at the end of their second semester during the academic year 2021. The learners' language performance was assessed by means of three sub-skills in the EFL achievement test.

The EFL achievement test is the official standard composite test which purports to test a number of skills. It is typically comprised of one reading text along with reading comprehension questions, language functions and composition tasks. This test we used was based on the 2019-2020 Baccalaureate examination pack issued by the National Center of Exams of the Ministry of Education in Morocco, and it was administered to students at the end of the 2020-2021 academic year. The exam score ranges between a minimum of 0 and a maximum of 40 .

As above-mentioned, the English achievement test comprises three tasks. The first sub-skill pertains to the reading comprehension course. An approximately 700-words passage in English followed by a variety of questions was constructed. The text was followed by multiple-choice questions assessing the learners' broader vocabulary recognition. This was followed by two 'inferential questions' (Davies \& Widdowson, 1974) which require from the learner to infer and seek information outside the content of the text. The third comprehension task purports to assess students' ability to understand English and paraphrase different sentences from the text.

The second battery is meant to assess students' mastery of the grammar course content. A number of typical items were introduced in this respect to measure the following: (1) accuracy in the use of tenses; (2) accuracy in handling the appropriate use of modals; (3) accuracy in exploiting correct grammatical structures related to the use of the passive voice; and (4) accuracy in handling reported speech structures. 
The third and last subtest was related to the writing skill. This free composition test was included in the battery mainly because of its integrative nature in measuring a number of objectives at the same time. Students are required to write a one-paragraph essay which satisfies the requirements of a good composition including the use of an appropriate topic sentence supported by at least three supporting sentences and a concluding sentence. Students were asked to pay meticulous attention to the mechanics of writing including indentation, capitalization, and punctuation.

The second test is the regional exam test and it is comprised of tests pertaining to multiple subjects in arts (e.g. Islamic education, history and geography) and languages (e.g. French and Arabic) at the end of the first-year Baccalaureate. With the assistance of the administration, we were able to have access to official records of the designated students the previous 2019-2020 academic year, which served as our measure for academic achievement.

To assess the significance of difference in the achievement levels of both male and female students along the sampled academic tests, a Chi-square test and independent samples t-tests have been implemented. This statistical measurement is deemed mandatory in research to evaluate whether the observed language achievements as obtained from the high school's official records of students' academic grades are statistically significant or they have just taken place by chance. As a matter of fact, this statistical measurement of significance of difference has been applied to evaluate all the results based on male-female students' academic grades.

It is worthy to note here that the statistical methods developed for this study have been processed through the exploitation of the Statistical Package for the Social Sciences (SPSS). The data were analyzed through the SPSS to find out the significance of difference in the achievement levels of both male and female university students. To display the results of this study, statistical data have all been processed employing the same statistical program.

\section{RESULTS}

A closer analysis of the available results demonstrates in concrete fashion the fact that sex differentiations in attainment are of overwhelming and considerable magnitude, as they do suggest that females outperform males with regards to the three English achievement tests in addition to the general composite EFL score. This particular pattern of results tends to confirm to a greater extent some of the theoretical hypotheses we stated before.

Before embarking on a detailed analysis of the data, it would perhaps be worthwhile stating some of the procedural techniques employed in the presentation of the results. In this respect, the learners' performances on the language-based achievement tests are broken down into different, but related subtests, the results of which are classified and dichotomized by sex. The score for each skill type is expressed as a percentage to allow statistical comparison between the groups. At the outset, the Chi-square test has been implemented in order to determine the existence, or lack thereof, of an effect of gender on success in EFL achievement.

\subsection{The Effect of Gender on EFL Achievement}

Before we get into a detailed examination of the potential differential success among the two sex groups making our selected sample, it is not only appropriate but also necessary to put the hypothesis of the effect of gender on EFL achievement (H1) to the test. For that purpose, a Chi-square test was performed to test the hypothesis at hand. The results indicated that gender indeed plays a significant role in the EFL achievement success, $\chi^{2}(1, N=151)=$ $21.78, p<.001$.

The obtained result is of crucial importance as it paves the way for us to confidently further our analyses at a more detailed level in the subsections to come. 


\subsubsection{Students' Scores on the General EFL Achievement and Academic}

\section{Achievement Tests}

With regard to group comparison, independent samples t-tests were conducted with the intent to assess the difference between the two sex groups in terms of academic achievement and EFL achievement. The results obtained show a significant difference between males and females in favor of female students in both EFL and academic achievement respectively, $\mathrm{t}(150)=-6.73, \mathrm{p}<.001 ; \mathrm{t}(150)=-11.69, \mathrm{p}<.001$ (See Table 1.1).

Table 1.1. Independent samples t-test results of comparison between male and female students in EFL achievement and academic achievement

\begin{tabular}{|c|c|c|c|c|c|c|}
\hline \multirow[t]{2}{*}{ Variables } & \multicolumn{2}{|c|}{$\begin{array}{c}\text { Men } \\
(n=75)\end{array}$} & \multicolumn{2}{|c|}{$\begin{array}{l}\text { Women } \\
(n=77)\end{array}$} & \multirow[b]{2}{*}{$t$} & \multirow[b]{2}{*}{$\mathrm{p}$} \\
\hline & M & $\mathrm{SD}$ & M & $\mathrm{SD}$ & & \\
\hline Academic achievement & 11.57 & 2.85 & 14.76 & 2.99 & -6.73 & .000 \\
\hline EFL achievement & 22.20 & 5.17 & 32.02 & 5.17 & -11.69 & .000 \\
\hline
\end{tabular}

The results which appear in Table 1 demonstrate two things of paramount importance. On the one hand, academic achievement operationalized as the regional exam score shows that females take the lead by a significant margin: males scored an average of $\mathrm{M}$ $=11.57, \mathrm{SD}=2.85$, while females scored an average of $\mathrm{M}=14.76, \mathrm{SD}=2.99$. On the other hand, the difference between males and females in EFL Achievement scores is also found to be significant. We can confidently say that at this stage, we are ready to examine whether the findings hold in a similar way for the three EFL subtests of Reading comprehension, the Grammar and Language, and Composition Subtests.

\subsubsection{Students' Scores on the EFL Achievement and Academic Subtests}

We have thus far statistically established an undisputable score advantage of females over males in terms of the general EFL score. We have subsequently used the same statistical test to assess the difference between the two sex groups across the subtests of Reading Comprehension, and Grammar and Language, and Composition. In a similar fashion, the results revealed a significant difference between males and females with female students being in the lead in terms of scores across all language skills tested as represented numerically in their respective order, $\mathrm{t}(150)=-7.92, \mathrm{p}<.001 ; \mathrm{t}(150)=-10.61, \mathrm{p}<.001$; $\mathrm{t}(150)=-9.78, \mathrm{p}<.001 ;($ See Table 1.2)

Table 1.2. Independent samples t-test results of comparison between male and female students in Reading comprehension, writing, and language functions scores

\begin{tabular}{|c|c|c|c|c|c|c|}
\hline \multirow{2}{*}{ Variables } & \multicolumn{2}{|c|}{$\begin{array}{c}\text { Men } \\
(\mathrm{n}=75)\end{array}$} & \multicolumn{2}{|c|}{$\begin{array}{l}\text { Women } \\
(\mathrm{n}=77)\end{array}$} & & \\
\hline & M & $\mathrm{SD}$ & M & $\mathrm{SD}$ & $t$ & $p$ \\
\hline
\end{tabular}




$\begin{array}{lccccc}\text { Reading Comprehension } & 9.54 & 2.37 & 12.57 & 2.32 & -7.92 \\ \text { Grammar and Language } & 9.09 & 2.47 & 12.88 & 1.87 & -10.61 \\ \text { Composition } & 3.67 & 1.76 & 6.58 & 1.89 & -9.78\end{array}$

\subsubsection{Students' Scores on the Reading Comprehension Subtest}

In view of the information gathered from the results of the comprehension subtest, we are reasonably led to contend that our hypothesis regarding the emergence of the achievement gap between the two sex groups with respect to this subtest has been confirmed. The situation in this result seems to substantiate female students' superiority over males in their attempt to understand the intended meaning of the passage, and to answer the corresponding vocabulary test questions.

Inspection of the findings pertaining to this subtest of comprehension demonstrates a trend of results which are in conformity with the wide spread view that female language learners tend to outstrip their male peers in a host of language abilities tests. Male learners are observed to lag behind than the female group. The result of the independent samples ttest, $\mathrm{t}(150)=-7.92, \mathrm{p}<.001$, for this dimension indicates that the difference in grades between the two sex groups is significant in favor of female students (See Table 2).

The proportion of students' success with respect to this subtest is highly indicative of female learners' performance. As opposed to boys who reached a mean score of merely 9.54, female language learners seem to excel in this regard averaging 12.57. By and large, the percentage of success among the two sex groups with respect to this subtest proved to be statistically discernible, yielding a difference of (3.03 score points) to the advantage of girls. By and large, female students are found to attain better grades on measures probing their knowledge of vocabulary than their male peers. The differences in mean scores are again observed to be quite discernible privileging females.

\subsubsection{Students' Scores on the Grammar and Language Subtest}

As can be gleaned from the statistical analyses outcome in Table 2, the results seem to be particularly impressive in view of the fact that there is a greater proportion among female learners, as opposed to a tiny minority among males, who have performed significantly well on this subtest. This grammar subtest tends to portray an appreciable amount of variance between the two sex groups with regard their performance levels on items requiring attention to the use of tenses, on items requiring accuracy in the use of modal verbs, and accuracy in the use of grammatical structures related to the passive voice and reported speech. Statistically, we obtained independent samples t-test results, $\mathrm{t}(150)=-10.61$, $\mathrm{p}<.001$, indicating a significant difference in terms of Language and Grammar grades between the two sex groups favoring female students (See Table 2).

If we consider the grammar subtest scores attained by the two sex groups, we notice that that the rate of achievement among female language learners is appreciably higher. The rate of success among male learners, by contrast, seems to be lower in this regard. By and large, the general results on this subtest proved to be statistically discernible, yielding a considerable difference of (3.79 score points) privileging female language learners.

\subsubsection{Students' Scores on the Composition Subtest}

In an attempt to scrutinize the data obtained from the performance on this composition subtest, one may observe that the rate of success among female students is higher if compared with that of males. In order to have a basis for comparison, attempts have 
been made to examine the quality of writings that our examinees have composed in this regard.

The presently available data seems to unravel the fact that there are on the whole more students among the female group as opposed to those among males who have managed to write coherent and meaningful paragraphs. Qualitatively speaking, their ideas are relevant to the topic of the one-paragraph essay; they are arranged and expressed via more precise and succinct formulations. The topic sentences are well written being backed up by different types of supporting sentences. The use of linking words, capitalization, and punctuation marks have all been well respected in their writings. Comparison between the previous subtest and the present one has brought forth a consistent superiority among female language learners.

Generally, the results drawn from this evaluation subtest of vocabulary seem to indicate that there are again discernible disparities in the percentages of success among the two sex groups. It follows from this that the rate of success among the two cohorts with regards to this writing subtest seems to maintain similar patterns of differences favoring in most cases female language learners.

The results are particularly impressive in view of the fact that there is a greater proportion among male learners, as opposed to females, who have performed significantly poorly on the whole. Their essays are very limited in scope; their style is awkward; even worse, their ideas are restricted in such a way that some of them could not exceed even four lines in composing their essays. The independent samples t-test result obtained for the writing skill is: $t(150)=-10.61, p<.001$. This implies that the difference is statistically significant.

\section{RESULTS AND DISCUSSION}

The present study was designed primarily for the purpose of understanding some empirical questions concerned with the status of the learner's sex in relation language learning, and thereby attempting to elucidate and refine some of the theoretical underpinnings of the whole issue. The quantitative data pertaining to students' learning grades displays a noticeable superiority among females as they are seen to outperform their male peers along the three language attainment scales.

The evidence previously summarized seems to be in accord with the claim that female learners have the tendency to outperform their male peers with regards to language learning abilities. A look at the issue from an overall framework may indicate that the available results tend to afford additional evidence in support of the rationales underlying the first trend surveyed the literature privileging female language learners.

The three achievement test results tend to complement each other, for each stresses a different, but related aspect of the learner's performance in English. Given this compatibility between these results, one would be led to reason that taken together they seem to back up the contention that female students are actually better than males in their English language attainments.

The rate of success among female learners seems to be higher than that of their male peers regarding their performance on the Reading Comprehension subtest, the Composition subtest, and the Grammar subtest. They seem to maintain a consistent superiority along the three language abilities subtests.

The evidence of this study which reports girl's superiority in language learning seems to contradict the findings of a number of other researchers like Ryckman and Peckham (1987); Batters (1986); Boyle (1981); Hutt (1979); and Collis and Williams (1987). The general assumption, as stipulated by these authors, that female learners are far more likely to underachieve in language learning seems to be challenged. 
However, albeit the findings of this study may not have concurred with researchers reporting boys' superiority (Hutt, 1979; Collis \& Williams, 1987), they do not stand in opposition to an abundant mass of evidence drawn from other more published studies concerned with the same issue (Powell, 1979; Ekstrand, 1980; Burstall, 1981; Stockard \& Wood, 1984; Riding \& Banner, 1986). This tendency to favor girls over boys with regards to language performance has recently been well-attested and stressed by several investigations (Licht et al., 1989; Halpern, 1992; Murphy, 2010; Główka, 2014; Benattabou, 1990; 2020; Khoumich \& Benattabou, 2020; Nadif \& Benattabou, 2021; Bouih et al., 2021).

Attitudinal and motivational variables have been widely discussed as relevant hypotheses to explain male-female differences in language learning (Bartley, 1970; Powell, 1979; Ludwig, 1983; Pitchard, 1987; Mickelson, 1989).The general picture emerging from the number of these studies is that female learners tend to hold more favorable attitudes towards the study of foreign languages (Pritchard, 1987).

The greater proneness of girls to opt for the learning of second or foreign languages may be attributable to their attitudes towards these languages. There is pretty much a unanimous opinion among a number of authors that females' success in language learning can be ascribed to the supposed femininity of all linguistic work (Robinson, in loveday, 1982), or to the belief that language learning, be it first, second, or foreign, is a females' domain par excellence (Powell, 1979; Halpern, 1986).

Such a view which stresses the link between language learning and 'femininity' has been supported by results from different studies. It has been demonstrated in this connection that girls are much more interested in second /foreign language learning because, for example, of the 'feminine image' French has in England (Pritchard, 1987), or because learning is regarded as directly relevant to their occupational aspirations (Burtstall, 1981), or because better attainments in a foreign language are believed to be an accomplishment appropriate for female learners than for males (Powell, 1979).

The hypothesis that sex variations can be accounted for in terms of the learner's different motivations and interests in language study may be sustained at least in part by Guebels' (1988) study of Moroccan learner's motivations for learning foreign languages in Morocco. Female students have been found to be more positively oriented towards the foreign language study than their male peers. This is evidenced by the overall number of girls who have shown their interest to learn English; $78 \%$ among females but only $72 \%$ among males.

Another alternative explanation stipulated to elucidate the origin of females' superiority over males emanates from the sex-role socialization hypothesis (kfir, 1988; Mickelson, 1989). It has been hypothesized in this respect that girls' tendency to outperform males may be attributed to their being more likely to conform and adapt to the school demands (Stockard, 1980; kfir, 1988). Mickelson (1989) endorses essentially the same view that girls are socialized to be good. It is important to note that the findings of the current study seem to resonate well with Hdii and Fagroud's findings (2018) which indicate that female students outperformed their male counterparts at almost all school subjects including English and French.

Also consistent with the results of this study are views which hypothesize that there are other mediating variables which could possibly engender sex differentiations in language learning. More evidence for this issue appears in a number of sociolinguistic studies concerned with the speech of men and women. The bulk of this literature abounds with statements in support of women's greater susceptibility to the prestigious forms of the language they use (Labov, 1970; Trudgill, 1972, 1974, 1983; Coates, 1986; Cameron \& Coates, 1988).

Highly suggestive perhaps, is Cameron and Coates' (1988) claim that females' strong adherence to more 'correct' and 'prestigious' forms of language can be applicable to the learning of a second language. This is tantamount to saying that women's sensitivity to what 
is prestigious is not only a first language phenomenon, but extends to a second language as well (Cameron \& Coates, 1988). Such a view seems to find expression in Loveday's (1982) argument that the reason why girls tend to have more access to second language learning is probably assigned to their being "much more conscious of standards norms and prestigious forms in their language than men." (p. 15).

As can be discerned from the above results, females have a higher mean score than do males in the three achievement subtests; the mean difference of all of them reaches the level of significance. This buttresses up our hypothesis for a female superiority.

Although the findings of this study are in complete concordance with the first trend in the literature which supports female learners outperformance with respect to language learning abilities, one should perhaps be wary of fully criticizing studies where sex differences have been reported to be in favor of boys, or studies reporting no significance as far as the effects of the sex parameter are concerned. This being the case mainly because sex differences might be culture-bound thereby yielding different sex patterns in accordance with different cultures. These comments bring us to the ultimate question of whether sex variations in relation to second/foreign language learning are universal and are manifested across cultures, or they are culture-bound.

The fact that different studies have reported different results concerning the problematic issue of the status of sex in language learning may lead one to be on his guard against accepting any extreme interpretation of the findings, and so generalizations must perhaps be made with due caution. Equally important, we are legitimately led to question the credibility of some general claims put forward by Carroll, 1975; and Lewis \& Massad, 1975 (both cited in Powell, 1979, p. 19), namely that the phenomenon that female learners tend to outperform males in second/foreign language learning is universal.

The present investigation, however, does in no way justify this rush to judgment. Although the bulk of the evidence drawn from our study indicates that female learners tend to attain higher levels in their academic grades than males, it is hard to generalize from this study that the phenomenon is universal without further evidence from more situations, more countries, more languages and more aspects of language achievement. It may well be that the hypothesis is correct, but it can hardly be said to be proved by the arguments included in this study.

This point has been stressed by a number of scholars concerned with sex variations in language learning (Hartly, 1978; Boyle, 1981; Faerch et al., 1984). The general consensus seems to favor the view that cross-cultural variations in sex-related experiences may differentially influence language attainment of gender groups (Zeidner, 1987). In view of our lack of knowledge about this hypothesis, Stockard (1980) argues that studies must be replicated in other settings to see whether this sex pattern is universal or culture bound.

It follows, therefore, that albeit female students are found to be more efficient in their language attainments than males, this study alone should not be used as a strong argument in favor of this hypothesis. Of course, this needs not be the last word on this issue, and more extensive research is required directly comparing the two sex groups before any definitive statements are possible.

\section{CONCLUSION}

A glance at the results from an overall framework will certainly disclose that there is a strong tendency among the female group to outscore the corresponding male one on most verbal ability tests including the Reading Comprehension, the Composition, and the Grammar subtests. Equally important, they are found to receive higher scores than their male peers on almost all units and items pertaining to the overall batteries of the achievement test. 
By and large, it would not perhaps be surprising to conclude that the vast body of research findings still does not adequately explain the phenomenon under prime concern. The suspicion remains that the variables upon which the bulk of research has been based are bound to be overwhelmed by other more mediating and confounding factors such as the learners' attitudes, their socio-economic background, the personality of the teacher, the context of experiment, just to name a few. If no definitive conclusions have been made, it is mainly because research pertaining to this area of study is still in dire need of more investigations and explorations.

A preliminary empirical investigation was conducted in the Moroccan context to explore the differential success of male-female students both with respect to their academic and EFL achievement. In conformance with the existing literature, the results have demonstrated a clear female superiority over their male counterparts in both academic achievement and EFL achievement. However, the present study is not without limitations. Two of the most important limitative aspects are the sample size and the sampling method. One strategy to counter these two limitations is to maximize the sample size many-fold on the one hand, and to conduct random sampling for the purposes of generalizability of findings on the other hand. An additional aspect linked to the previous point is the diversification of the sample for the purposes of representativeness through widening the sample selection pool to include multiple schools preferably across multiple regions throughout the kingdom. There are reasons to believe that this will result in a better and more reliable outcome. The results will also be more interpretable as the larger the sample, the less are statistical errors undermining and even preventing firmly conclusive interpretations. Likewise, the generalizability of our findings is constrained by the use of a high school student sample and does not extend its selection to university and junior school students. To remedy this, we suggest a multiple-study article that undertakes the study of multiple samples cross-sectionally in order to reveal any potential consistency of female academic outperformance across multiple educational levels.

\section{REFERENCES}

Albani, A., \& Sewell, P. M. (1979). Motivation for learning French at secondary and tertiary levels. Applied Linguistics, 17(3), 149-158.

Alexander, K. L., \& Eckland, B. K. (1974). Sex differences in the educational attainment process. American Sociological Review, 39(5), 668-682. https://doi.org/10.2307/2094313

Bacon, S. M. (1992). The relationship between gender, comprehension, processing strategies, and cognitive and affective response in foreign language listening. The Modern Language Journal, 76(2), 160-178. https://doi.org/10.2307/329769

Bacon, S. M., \& Finnemann, M. D. (1992). Sex differences in self-reported beliefs about foreign-language learning and authentic oral and written input. Language Learning, 42(4), 471-495. https://doi.org/10.1111/j.1467-1770.1992.tb01041.x

Bartley, D. E. (1970). The importance of the attitude factor in language dropout: A preliminary investigation of group and sex differences. Foreign Language Annals, 3(3), 383-393. https://doi.org/10.1111/j.1944-9720.1970.tb01292.x

Batters, J. (1986). Do boys really think languages are just girl-talk. Modern Languages, 67(2), 75-79. 
Beaudin, B., Horvath, J., \& Wright, S. (1992). Predicting freshman persistence in economics: A gender comparison. Journal of the First-Year Experience \& Students in Transition, $4(2), 69-84$.

Benattabou, D. (1990). The Significance of the Factors of Age and Sex in the Learning of a Second Language: A Case Study of Moroccan Learners. Unpublished MA Dissertation, Sidi Mohammed Ben Abdellah University, Fes, Morocco.

Benattabou, D. (2020). Gender imbalances in the visual discourse of Moroccan EFL textbooks: A critical image analysis. Journal of Translation and Language Studies, 1(1), 1-25. https://doi.org/10.48185/jtls.v1i1.20

Benattabou, D. (2021). Gendered Hegemony in the Visual Discourse of Moroccan EFL Textbooks: A Quantitative Content Analysis. International Journal of Linguistics and Translation Studies, 2(1), 40-61. https://doi.org/10.36892/ijlts.v2i1.103

Benattabou, D. (2021). The visual 'Masculinization' of Moroccan EFL textbooks: A social semiotic analysis. Feminist Research, 5(1), 1-19. https://doi.org/10.21523/gcj2.21050101

Bouih, A., Nadif, B., \& Benattabou, D. (2021). Assessing the Effect of General Self-efficacy on Academic Achievement Using Path Analysis: A Preliminary Study. Journal of English Language Teaching and Applied Linguistics, 3(4), 18-24. https://doi.org/10.32996/jeltal.2021.3.4.3

Boyle, J. P. (1987). Sex differences in listening vocabulary. Language Learning, 37(2), 273284. https://doi.org/10.1111/j.1467-1770.1987.tb00568.x

Brigui, H. (2017). The Relationship between Moroccan EFL University Students' Motivation Orientation and Their Classroom Participation: Exploring the Variables of Gender and Proficiency Level. Journal of Education and Practice, 8(3), 108-112.

Brown, H.D. (1986). Principles of Language Learning and Teaching. Prentice Hall.

Bügel, K., \& Buunk, B. P. (1996). Sex differences in foreign language text comprehension: The role of interests and prior knowledge. The Modern Language Journal, 80(1), 1531. https://doi.org/10.1111/j.1540-4781.1996.tb01133.x

Burstall, C. (1981). Primary French in the balance. In J.B. Pride (Ed.). Sociolinguistic Aspects of Language Learning and Teaching. Oxford University Press.

Byrne, B. M. (1994). Structural equation modeling with EQS and EQS/Windows: Basic concepts, applications, and programming. Sage.

Byrnes, J. P. (2005). Gender Differences in Math: Cognitive Processes in an Expanded Framework. In A. M. Gallagher \& J. C. Kaufman (Eds.), Gender differences in mathematics: An integrative psychological approach (pp. 73-98). Cambridge University Press.

Camarata, S., \& Woodcock, R. (2006). Sex differences in processing speed: Developmental effects in males and females. Intelligence, 34(3), 231-252. https://doi.org/10.1016/j.intell.2005.12.001 
Cameron, D., \& Coates, J. (1988). Some problems in the sociolinguistic explanation of sex differences. In J. Coates \& D. Cameron (Eds.), Women in their Speech Communities (pp. 13-26). Longman.

Chambers, J. K. (1992). Linguistic correlates of gender and sex. English World-Wide, 13(2), 173-218. https://doi.org/10.1075/eww.13.2.02cha

Coates, J. (1986). Women, Men, and Language. Longman.

Coates, J. (1987). Epistemic modality and spoken discourse. Transactions of the Philological society, 85(1), 110-131. https://doi.org/10.1111/j.1467-968X.1987.tb00714.x

Collis, B. A., \& Williams, R. L. (1987). Cross-cultural comparison of gender differences in adolescents' attitudes toward computers and selected school subjects. Journal of Educational Research, 81(1), 17-27. https://doi.org/10.1080/00220671.1987.10885792

Connor, U. (1983). Predictors of second language reading performance. Journal of Multilingual and Multicultural Development, 4(4). 271-288. https://doi.org/10.1080/01434632.1983.9994116

Dale, R. R. (2017). Mixed or Single-Sex School? Volume 3: Attainment, Attitudes and Overview. Routledge.

Davies, A., \& Widdowson, H. (1974). The teaching of reading and writing. In J. P. B. Allen \& S. P. Corder (Eds.), Techniques in applied linguistics (Vol. 3). Oxford University Press.

Dillon, J. T. (1982). Male-female similarities in class participation. The Journal of Educational Research, 75(6), 350-353. https://doi.org/10.1080/00220671.1982.10885408

Dörnyei, Z., \& Ottó, I. (1998). Motivation in action: A process model of motivation. Working Papers in Applied Linguistics, 4, 43-69.

Dörnyei, Z., \& Csizér, K. (2005). The effects of intercultural contact and tourism on language attitudes and language learning motivation. Journal of language and social psychology, 24(4), 327-357. https://doi.org/10.1177/0261927X05281424

Burt, M. K., Dulay, H. C., \& Krashen, S. D. (1982). Language Two. Oxford University Press.

Dweck, C. S., \& Licht, B. G. (1980). Learned Helplessness and Intellectual Achievement. In J. Garber, \& M. E. P. Seligman (Eds.), Human Helplessness: Theory and Application. Academic Press.

Ehrman, M. \& Oxford, R. L. (1989). Effects of sex differences, career choice, and psychological type on adult language learning strategies. The Modern Language Journal, 73 (1), 1-13. https://doi.org/10.2307/329394

Ehrman, M. E., \& Oxford, R. L. (1995). Cognition plus: Correlates of language learning success. The modern language journal, 79(1), 67-89. https://doi.org/10.1111/j.15404781.1995.tb05417.x

Eisenstein, M. (1982). A study of social variation in adult second language acquisition. Language Learning, 32(2), 367-391. https://doi.org/10.1111/j.14671770.1982.tb00977.x 
Ekstrand, L. H. (1980). Sex differences in second language learning? Empirical studies and a discussion of related findings. Applied Psychology, 29(1-2), 205-259. https://doi.org/10.1111/j.1464-0597.1980.tb00891.x

Ellis, R. (1995). Understanding Second Language Acquisition. Oxford University Press.

Færch, C., Haastrup, K., \& Phillipson, R. (1984). Learner language and language learning. Multilingual Matters.

Farhady, H. (1982). Measures of language proficiency from the learner's perspective. TESOL quarterly, 16(1), 43-59. https://doi.org/10.2307/3586562

Flege, J. E. (1987). A critical period for learning to pronounce foreign languages? Applied Linguistics, 8(2), 162-177. https://doi.org/10.1093/applin/8.2.162

Fergusson, D.M., \& Horwood, L.J. (1997). Gender differences in educational achievement in a New Zealand birth cohort. New Zealand Journal of Educational Studies. 32(1), 83-96.

Gall, M. D., \& Gall, J. P. (1976). The discussion method. In N. L. Gage (Ed.), The Psychology of Teaching Methods. University of Chicago Press.

Gardner, R. C., \& Lambert, W. E. (1972). Attitudes and Motivation in Second-Language Learning. Newbuty House.

Gardner, R. C. (1985). Social Psychology and Second Language Learning: The Role of Attitudes and Motivation. Edward Arnold. https://doi.org/10.1037/h0083787

Gardner, R. C. (1988). The socio-educational model of second-language learning: Assumptions, findings, and issues. Language learning, 38(1), 101-126. https://doi.org/10.1111/J.1467-1770.1988.TB00403.X

Guebels, V. (1988). La motivation pour les langues étrangères chez les lycéens de Rabat. Revue Marocaine de Didactique des Langues, 1, 25-38.

Halpern, D. F. (1992). Sex Differences in Cognitive Abilities (2nd ed.). Lawrence Erlbaum Associates.

Hartford, B. (1978). Phonological differences in the English of adolescent female and male Mexican-Americans. International Journal of the Sociology of Language, 1978(17), 55-64. https://doi.org/10.1515/ijsl.1978.17.55

Hartley, D. (1978). Teachers' definitions of boys and girls: Some consequences. Research in Education, 20(1), 23-35. https://doi.org/10.1177/003452377802000103

Hdii, S. \& Fagroud, M. (2018). The effect of gender on university students' school performance: The case of the National School of Agriculture in Meknes, Morocco. Culture \& Society, 9(1), 67-78. http://dx.doi.org/10.7220/2335-8777.9.1.4

Hennesy, J. J., \& Merrifield, P. R. (1978). Ethnicity and sex distinctions in patterns of aptitude factor scores in a sample of urban high school seniors. American Educational Research Journal, 15(3), 385-389. https://doi.org/10.2307/1162492

Hutt, C. (1979). Why Do Girls Underachieve?. Trends in Education, 4, 24-28. 
Ibourk, A. (2013). Determinants of Educational Achievement in Morocco: A MicroEconometric Analysis Applied to the TIMSS Study. International Education Studies, 6(12), 25-36.

Gass, S. \& Varonis, E. (1986). Sex differences in non-native speaker interactions. In R. Day (Ed.), Talking to Learn: Conversation in Second Language Acquisition, (pp. 327351). Newbury House.

Główka, D. (2014). The impact of gender on attainment in learning English as a foreign language. Studies in Second Language Learning and Teaching, 4(4), 617-635. https://doi.org/10.14746/SSLLT.2014.4.4.3

Graham, S., \& Rees, F. (1995). Gender differences in language learning: The question of control. Language Teaching Journal, 11, 18-19. https://doi.org/10.1080/09571739585200061

Green, L. \& Foster, D. (1986). Classroom Intrinsic Motivation: Effects of Scholastic Level, Teacher Orientation, and Gender. Journal of Educational Research, 80(1), 34-39. https://doi.org/10.1080/00220671.1986.10885718

Jiménez, R. M. (2003). Sex differences in L2 vocabulary learning strategies. International Journal of Applied Linguistics, 13(1), 54-77. https://doi.org/10.1111/14734192.00037

Jiménez, R. M., \& Terrazas, M. (2008). The receptive vocabulary of EFL young learners. Journal of English Studies, 5-6(2005-2008), 173-191.

Johnson, J. S., \& Newport, E. L. (1989). Critical period effects in second language learning: The influence of maturational state on the acquisition of English as a second language. Cognitive psychology, 21(1), 60-99. https://doi.org/10.1016/0010028590003-0

Kinard, E., \& Reinherz, H. (1986). Birth date effects on school performance and adjustment: A longitudinal study. Journal of Educational Research, 79(6), 366-372. https://doi.org/10.1080/00220671.1986.10885707

Kipnis, D. (1976). Intelligence, occupational status \& achievement orientations. B. Lloyd \& J. Asher (Eds.), Exploring Sex Differences. Academic Press.

Kfir, D. (1988). Achievements and aspirations among boys and girls in high school: A comparison of two Israeli ethnic groups. American Educational Research Journal, 25(2), 213-236. https://doi.org/10.2307/1163081

Khoumich, A. \& Benattabou, D. (2020). Students' perceptions of teachers' gender-biased treatments in the classroom context. International Journal of Linguistics, Literature and Translation. 3(10), 174-187. https://doi.org/10.32996/ijllt.2020.3.10.20

Lambert, W. E. (1969). Psychological Aspects of Motivation in Language Learning. Bulletin of the Illinois Foreign Language Teachers Association, May, 5-11.

Labov, W. (1970). The logic of nonstandard English. In F. Williams (Ed.), Language and poverty: Perspectives on a theme (pp. 153-189). Markham.

Licht, B. G., \& Dweck, C. S. (1984). Sex differences in achievement orientations: Consequences for academic choices and attainments. In M. Marland (Ed.), Sex differentiation and schools (pp. 47-62). Heinemann Educational Books. 
Licht, B., Stader, S. \& Swenson, C. (1989). Children's Achievement-related beliefs: Effects of academic area, sex, and achievement level. Journal of Educational Research. 82(5), 253-260. https://doi.org/10.1080/00220671.1989.10885903

Lindberg, S. M., Hyde, J. S., Petersen, J. L., \& Linn, M. C. (2010). New trends in gender and mathematics performance: A meta-analysis. Psychological Bulletin, 136(6), 11231135. https://doi.org/10.1037/a0021276

Loveday, L (1982). The Sociolinguistics of Learning and Using a Non-native Language. Pergamon Press.

Ludwig, J. (1983). Attitudes and expectations: A profile of female and male students of college French, German, and Spanish. The Modern Language Journal, 67(3), 216227. https://doi.org/10.2307/327078

Lynn, R., Fergusson, D. M., \& Horwood, L. J. (2005). Sex differences on the WISC-R in New Zealand. Personality and Individual Differences, 39(1), 103-114. https://doi.org/10.1016/j.paid.2004.12.009

Maccoby, E. E., \& Jacklin, C. N. (1974). The psychology of sex differences. Stanford University Press.

Maccoby, E. E., \& Jacklin, C. N. (1980). Sex differences in aggression: A rejoinder and reprise. Child development, 51(4), 964-980. https://doi.org/10.2307/1129535

Markham, P. L. (1988). Gender differences and the perceived expertness of the speaker as factors in ESL listening recall. TESOL Quarterly, 22(3), 297-406. https://doi.org/10.2307/3587286

McCornack, R. L., \& McLeod, M. M. (1988). Gender bias in the prediction of college course performance. Journal of Educational Measurement, 25(4), 321-331. https://doi.org/10.1111/j.1745-3984.1988.tb00311.x

Mickelson, R. (1989). Why Does Jane Read and Write so Well? The Anomaly of Women's Achievement.Sociology of Education, 62(1), 47-63. https://doi.org/10.2307/2112823

Mickelson, R., \& Greene, A. (2006). Connecting Pieces of the Puzzle: Gender Differences in Black Middle School Students' Achievement. The Journal of Negro Education, 75(1), $34-48$

Miller, P., \& Dale, R. (1972). The Academic Progress of Male and Female First Year University Students Compared. Research in Education, 8(1), 56-60.

Miller, P. M., \& Dale, R. R. (1972). The Academic Progress of Male and Female First Year University Students Compared. Research in Education, 8(1), 56-60. https://doi.org/10.1177/003452377200800105

Morris, L.A. (1998). Differences in men's and women's ESL writing at the junior college level: Consequences for research on feedback. The Canadian Modern Language Review/ La Revue canadienne des langues vivantes, 55(2), 219-38. https://doi.org/10.3138/cmlr.55.2.219 
Murphy, B. (2010). Foreign language learning in Irish second level schools: gender very much on the agenda!. Irish Educational Studies, 29(1), 81-95. https://doi.org/10.1080/03323310902884367

Nadif, B., \& Benattabou, D. (2021). Rethinking the Insights from Good Language Learner Studies: Moroccan Learners of EFL as a Case Study. International Journal of Linguistics, Literature and Translation, 4(3), 61-73. https://doi.org/10.32996/ijllt.2021.4.3.7

Nyikos, M. (1990). Gender-related differences in adult language learning: Socialization and memory factors. Modern Language Journal, 74(3), 273-287. https://doi.org/10.2307/327624

Oakley, A. (1972). Sex, Gender and Society. Temple Smith.

Oxford, R., Nyikos, M., \& Ehrman, M. (1988). Vive la difference? Reflections on sex differences in use of language learning strategies. Foreign Language Annals, 21(4), 321-329. https://doi.org/10.1111/j.1944-9720.1988.tb01076.x

Oxford, R. (1992). Who are our students? A synthesis of foreign and second language research on individual differences with implications for instructional practice. TESL Canada Journal, 9(2), 30-49. https://doi.org/10.18806/tesl.v9i2.602

Peterson, S. (2000). Fourth, sixth, and eighth graders' preferred writing topics and identification of gender markers in stories. The Elementary School Journal, 101(1), 79-100. https://doi.org/10.1086/499660

Pica, T., Holliday, L., Lewis, N., Berducci, D., \& Newman, J. (1991). Language learning through interaction: What role does gender play? Studies in second language acquisition, 13(3), 343-376. https://doi.org/10.1017/S0272263100010020

Pomerantz, E. M., Altermatt, E. R., \& Saxon, J. L. (2002). Making the grade but feeling distressed: Gender differences in academic performance and internal distress. Journal of Educational Psychology, 94(2), 396-404. https://doi.org/10.1037/00220663.94.2.396

Powell, R.C. (1979). Sex differences in language learning: A review of the evidence. AudioVisual Language Journal, 17(1), 19-24.

Pritchard, R. M. O. (1987). Boys' and girls' attitudes towards French and German. Educational Research, 29(1), 65-72. https://doi.org/10.1080/0013188870290108

Riding, R. J., \& Banner, G. E. (1986). Sex and personality differences in second language performance in secondary school pupils. The British Journal of Educational Psychology, 56(3), 366-370. https://doi.org/10.1111/j.2044-8279.1986.tb03050.x

Ryckman, D. B., \& Peckham, P. (1987). Gender differences in attributions for success and failure situations across subject areas. Journal of Educational Research, 81(2), 120125. https://doi.org/10.1080/00220671.1987.10885808

Sadiqi, F. (2003). Women and linguistic space in Morocco. Women and Language, 26(1), $35-43$.

Sadiqi, F. (2011). A Genesis in gender and women studies in Morocco.Women's Studies North and South International Conference Bellagio Center, Italy, 13-17. September 2011. 
Safsouf, Y., Mansouri, K., \& Poirier, F. (2020). An analysis to understand the online learners' success in public higher education in Morocco. Journal of Information Technology Education, 19, p. 87-112. https://doi.org/10.28945/4518

Scarcella, R., \& Zimmerman, C. (1998). Academic words and gender: ESL student performance on a test of academic lexicon. Studies in Second Language Acquisition, 20(1), 27-49.

Schumann, J. H. (1980). Affective factors and the problem of age in second language acquisition. In W. Croft (Ed.), Readings of English as a Second Language. (pp. 222 246). Winth Inc.

Soori, A., \& Zamani, A. A. (2012). Language features in their writing of male and female students in English and Persian. European Journal of Social Sciences, 33(2), 324 329.

Stockard, J. (1980). Gender equity and education. Annual Review of Research in Education.

Stockard, J., \& Wood, J. W. (1984). The myth of female underachievement: A reexamination of sex differences in academic underachievement. American Educational Research Journal. 21(4), 825-838. https://doi.org/10.3102/00028312021004825

Strevens, P. (1983). Teaching English as an International Language. Pergamon Press.

Sunderland, J. (1994). Introduction. In J. Sunderland (Ed.), Exploring Gender: Questions and Implications for English language education (pp. 55-66). Prentice Hall.

Sunderland, J. (2000). Issues of language and gender in second and foreign language education. Language Teaching, 33(4), 203-223. https://doi.org/10.1017/S0261444800015688

Sunderland, J. (2010). Theorizing gender perspectives in foreign and second language learning. In R.M.J. Catalán (Ed.), Gender Perspectives on Vocabulary in Foreign and Second Languages (pp. 1-19). Palgrave Macmillan. https://doi.org/10.1057/9780230274938_1

Svanes, B. (1987). Motivation and cultural distance in second language acquisition. Language Learning, 37(3), 340-359. https://doi.org/10.1111/j.14671770.1987.tb00575.x

Thompson, G. B. (1975). Sex differences in reading attainments. Educational Research,

18(1), 16-23. https://doi.org/10.1080/0013188750180102

Trudgill, P. (1972). Sex, covert prestige and linguistic change in the urban British English of

Norwich. Language in society, 1(2), 179-195. https://doi.org/10.1017/S0047404500000488

Trudgill, P. (1974). The Social Differentiation of English in Norwich. Cambridge University Press.

Trudgill, P. (1983). Sociolinguistics: An Introduction to Language and Society. Penguin.

Tuckman, H. P. (1975). Teacher effectiveness and student performance. The Journal of Economic Education, 7(1), 34-39. https://doi.org/10.1080/00220485.1975.10845419 
Wen, Q., \& Johnson, R. K. (1997). L2 learner variables and English achievement: A study of tertiary-level English majors in China. Applied linguistics, 18(1), 27-48. https://doi.org/10.1093/applin/18.1.27

Williams, D. (1981). Factors related to performance in reading English as a second language. Language Learning, 31(1), 31-50. https://doi.org/10.1111/j.14671770.1981.tb01371.x

Woodley, A. (1984). The older the better? A study of mature student performance in British Universities. Research in Education, 32(1), 35-50. https://doi.org/10.1177/003452378403200105

Zaid, H. (2020). Self-Efficacy, Academic Motivation and Achievement among Moroccan EFL Learners. In F. Bouhadiba, M. Hicham \& H. M. Aabi (Eds), Issues in Education Quality: Higher Education. Ibn Zohr University.

Zeidner, M. (1987). A comparison of ethnic, sex and age bias in the predictive validity of English language aptitude tests: Some Israeli data. Language Testing, 4(1), 55-71. https://doi.org/10.1177/026553228700400106

Zohri, A. (2011). Causal Attributions for Failure and the Effect of Gender among Moroccan EFL University Learners. English Language Teaching, 4(4), 130-137.

\section{$\underline{\text { AUTHORS'BIO }}$}

Driss Benattabou is a full professor of English at the Department of English, Faculty of Arts and Humanities, Meknes, Morocco. He holds a Ph.D. from Moulay Ismail University, Meknes, Morocco. He has published a number of articles in such research areas as Applied Linguistics, Gender in Education, Critical Discourse Analysis and Visual semiotics. He is a reviewer and a full member of six internationally indexed journals.

Mounir Kanoubi is a teacher-researcher of English at the Institut Universitaire de Technologie, attached to the Rectorate of Rouen, France. His research interests revolve around such areas as Applied Linguistics, English for Specific Purposes, and Gender Studies.

Abdelouahed Bouih is a PhD Candidate, English Department, Moulay Ismail University, Meknes, Morocco. He has published a number of articles in such research areas as Applied Linguistics, gender studies, among other research interests.

Bendaoud Nadif is a PhD candidate at the Department of English, Faculty of Arts and Humanities, Meknes, Morocco. His research interests revolve around such areas as Applied Linguistics, EFL learning and teaching, and Good Language Learner Research. He has facilitated many webinars both nationally and internationally.

Mohamed Benhima is a PhD holder from the Department of English, Faculty of Arts and Humanities, Fez, Morocco. His research interests revolve around such areas discourse 
analysis, core linguistics, and EFL learning and teaching. He has published multiple articles both national and international journals. 